\title{
EXISTÊNCIA E CULPABILIDADE UM ESTUDO DO PARÁGRAFO 58 DE SER E TEMPO, DE MARTIN HEIDEGGER
}

\author{
Livio Osvaldo Arenhart*
}

SINTESE - Em consonância com o método fenomenológico-hermenêutico traçado por Martin Heidegger em Sein und Zeit (1927), a expressão prático-auto-referencial "eu sou" [sum] deve anteceder toda predicação sobre 0 humano ser/ estar-aí-no-mundo. A este pertence a culpa/ divida [Schuld] enquanto sentir-se/compreender-se e confessar-se como ser-culpado/devedor [Schuldigsein]. "Sou culpado por" resulta da junção de "sou responsável por" com o "não" implícito na idéia (objetivista) de falta (relativa à realização de um ideal valorizado). 0 responder ativo-projetivo do ser-aí [Dasein] por seu ter-queser está marcado, prévia e ontologicamente, pela impossibilidade de autofundação e pela possibilidade, sempre iminente, de não-(mais)-ser/estarai-no-mundo; e, no plano ôntico, está permeado pela necessária restrição de possibilidades de ação e pelo inelutável retraimento a possibilidades alternativas. $O$ texto explicita algumas potencialidades de incidência corretiva deste conceito ontológico-existencial de culpa sobre a autocompreensão do homem contemporâneo.

PALAVRAS-CHAVE - existência, negatividade, autenticidade, culpabilidade.
ABSTRACT - According to the hermeneuticphenomenological method drawn by Martin Heidegger in Sein und Zeit (1927), the practical self-reference expression "I am" [sum] must precede any statement over the human bearound-in-the-world. To the later belongs the guilt [Schuld] as feeling, understanding, and declaring himself as being-guilty [Schuldigsein]. "I am guilty for" derives from the union of "I am responsable for" with the "no" implicit in the idea (objectivist) of lack (relative to the fulfillment of a praised ideal). The active-projective assuming of the to-be-around [Dasein] for the his must-be is characterized, beforehand and ontologically, by the impossibility of selffoundation and by the possibility, always imminent, of the no-(more)-be-around-in-theworld; and, on the onthic level, it is permeated by the necessary restriction to action possibilities and the ineluctable withdrawal in terms of possible alternatives. The text explicits some possibilities of a corrective incidence of the ontological-existential concept of guilt over contemporary man's self-understanding.

KEY WORDS - existency, negativity, authenticity, culpability

* Professor de Filosofia e Psicologia da Universidade Regional Integrada do Alto Uruguai e das Missōes - URI, Santo Ângelo, RS.

\begin{tabular}{|l|l|l|l|l|l} 
VERITAS & Porto Alegre & v. 43 & $\mathrm{n}^{0} 1$ & Março 1998 & p. $5-23$ \\
\hline
\end{tabular}




\section{Introdução}

$\mathrm{Na}$ interpretação cotidiana do existir humano, o tema da culpa aparece com muita freqüência. Pedagogos denunciam práticas educacionais que, através de ordens e proibições, incutiriam nas crianças sentimentos exagerados de culpa. Diagnósticos psicológicos detectam a culpa como um sintoma muitíssimo freqüente nas pessoas que buscam a clínica. Rituaịs de purificação, penitência e prevenção contra a desgraça assumem formas cada vez mais diversas e sofisticadas, mesmo fora dos sistemas religiosos.

A resistência tenaz dos sentimentos de angústia e culpa aos sofisticados rituais de purificação e ao desmantelamento psicoterápico tornou inevitável a suspeita em relação às teorias que, em base ao princípio da razão suficiente, supöem uma causa simples da culpa, localizável em determinado momento da ontogênese (teorias psicodinâmicas) ou da filogênese humana (parricídio tribal histórico ou "pecado original" no quase-começo da História).

A questão da culpa está relacionada com a questão ética ineludível da sanção interna, ou seja, com o fenômeno de alguém se considerar a si mesmo digno de desprezo (envergonhado) diante de si e diante dos outros no caso de e por causa de uma violação de normas morais internalizadas. Ressalve-se, porém, de saída, que os dois fenômenos não são comensuráveis: por um lado, pode haver culpa que não seja culpa moral, isto é, em relação a possibilidades de ação não prescritas pelo código moral compartilhado/internalizado e, por outro lado, a sanção interna não depende exclusivamente da possibilidade existencial de ser e sentir-se culpado.

A idéia de culpa, por definição, abarca duas idéias: primeiro, a idéia de que eu me sinto/compreendo como sendo responsável pelo ato (que não precisa ser moral) em relação ao qual eu me sinto/compreendo culpado; segundo, a idéia de não ter realizado $\mathrm{a}(\mathrm{s})$ possibilidade(s) de ação (moral ou não) que eu sinto/compreendo que deveria ter realizado, ou de ter realizado a possibilidade de ação que eu sinto/compreendo não dever ter realizado.

Talvez por se desvelar, paradoxalmente, como frágil fator constituinte do simesmo e, ao mesmo tempo, como "algo" forte e imponente que se abate sobre o si-mesmo, a consciência (da culpa), no decorrer da História da Filosofia, tem sido abordada menos teorético-explicativamente do que metaforicamente. $\mathrm{E}$ as metáforas mais utilizadas são as da "voz" e do "tribunal" (Etxeberria, 1995, p. 86-87).

Perante os juizes atenienses que o condenaram, Sócrates justificou o seu apreço à virtude pela intimação de um deus, que the falaria interiormente, convocando-o à missão de filosofar, examinar-se a si e aos outros, advertir e aconselhar os homens, censurá-los e persuadi-los a se ocuparem da virtude (Platão, 1972, p. 84ss.; Nunes, 1992, p. 124). O patrono da Filosofia assegurava que, invariavelmente, procurou cumprir as ordens que havia recebido do deus e que a voz deste deus tem marcado a sua oposição sempre que ele, Sócrates, esteve prestes a fazer o mal (Platão, 1972, p. 85, 88, 103-104). Foi essa voz interior da divindade que o fez abster-se da vida pública, ou seja, retirar-se do "círculo da gente" (Id., p. 88; Nunes, 1992, p. 125). Nem mesmo a ameaça de morte fê-lo quebrar a fidelidade ao 
deus por cuja voz se orientava desde a infância, de tal modo que a considerava "a minha voz interior habitual" (Platão, 1972, p. 85, 88, 104).

O Vigário Saboiardo de Rousseau, em sua Profissão de fé, identificou a voz da consciência a uma voz celeste e imortal, atuante "no fundo das almas". Rousseau converteu o deus socrático num "princípio inato de justiça e de virtude", numa "instância judicativa, aplicando normas universais", base dos nossos julgamentos morais. "Não é mais a voz, como em Sócrates, que absorve a consciência, e sim a consciência que absorve a voz" (Nunes, 1992, p. 125-126).

De Rousseau para Kant, num passo apenas, a voz da consciência é convertida em voz de um juiz interno: "Kant orientou a sua interpretação da consciência pela 'representação de um tribunal'” (ST, II, p. 82). Na reflexão prática nos julgamos a nós mesmos: "Eu, o juiz, e também o julgado, sou a mesma pessoa" (Kant apud Kutschera, 1989, p. 270). A lei moral kantiana obriga incondicionalmente, tendo que se conformar a ela a máxima de conduta do indivíduo em todas as suas ações por respeito ao dever. Do exercício do poder de agir contra a lei moral deriva a culpa como "uma maneira de se considerar perante uma espécie de tribunal invisivel que mede a ofensa, pronuncia a condenação e inflige a punição" (Ricoeur, s.d., p. 419. O grifo é meu). A propósito, podemos ler na Crítica da razão prática: "Um homem pode usar de todos os recursos para justificar ação contrária à lei, alegando que o fez por erro involuntário ou simples inadvertência, coisas que, por outro lado, nem sempre são possíveis de evitar; pode, ainda, encontrar-se em uma situação desagradável, arrastado por uma necessidade natural e, contudo, declarar-se inocente; não obstante isso, pensará sempre que o advogado que pleitear em seu favor não pode, de modo algum, sufocar em si o acusador, caso tenha tão somente consciência de que no tempo em que praticou a injustiça se encontrava em perfeito juizo, isto é, em pleno uso de sua liberdade" (s.d., p. 154).

$\mathrm{Na}$ Introdução às suas Lições sobre a Filosofia da História, Hegel deixou registrado que o ser humano "sabe o que é o bem e o que é o mal e sabe que seu destino é a sua própria capacidade de escolher o bem ou o mal" (Hegel, 1990, p. 84). Hegel esteve particularmente atento ao aspecto incomensurável da práxis, ou seja, ao fenômeno da "superabundância de efeitos imprevistos e involuntários" dos atos humanos individuais (Id.: 74ss.). Da tematização deste fenômeno inferiu que nenhum ser humano é inocente [unschuldig], seja no plano da moral intrínseca [Moralität] seja no plano da moral extrínseca da posição social [Sittlichkeit] (Id., p. 84; Luijpen, 1973, p. 218ss.).

Nietzsche mostra como a culpa, a dívida e o dever estão, originariamente, imbricados. Na Segunda dissertação de para a genealogia da moral podemos ler: "O sentimento de culpa, da obrigação pessoal $[\ldots]$ teve sua origem na mais antiga $e$ mais originária relação pessoal que há, na relação entre comprador e vendedor, credor e devedor: aqui entrou pela primeira vez pessoa contra pessoa, aqui se mediu pela primeira vez pessoa a pessoa" (1974, p. 313). E mais adiante: "Também a comunidade está para seus membros naquela importante relação, a do credor para seus devedores" (Id., p. 314). O filósofo explica que o membro está empenhado e obrigado com a comunidade porque mora protegido, poupado, em paz e confiança, descuidado quanto a certos danos e hostilidades aos quais o 
homem de fora está exposto. Assim sendo, o infrator é um devedor que, além de não pagar pelas vantagens e adiantamentos, atenta contra o seu credor. Por isso, cabe à comunidade credora 0 direito de punir o infrator-devedor, lançando-o fora de si, quer dizer, subtraindo-o dos seus bens e vantagens e levando-o a dar-se conta do quanto valem esses bens (Id., p. 314-315). Não passou despercebido a Nietzsche que esse esquema tende a ser transferido para a relação dos humanos com suas respectivas divindades. Neste contexto, está obstruída a descarga dos velhos instintos da liberdade, tendo que voltar-se "para trás, contra o homem mesmo", seu possuidor. "Essa é a origem da 'má consciência'. O homem que, por falta de inimigos e resistências externas, encerrado à força em uma opressiva estreiteza e regularidade dos costumes, dilacerava, perseguia, roía, espreitava, maltratava impacientemente a si mesmo, esse animal batendo-se e ferindo-se contra as barras de sua jaula, e que se quer 'amansar', esse animal passando privação e devorado pela saudade do deserto, que de si mesmo tinha de fazer uma aventura, uma câmara de suplício, uma insegura e perigosa selva, esse parvo, esse nostálgico e desesperado prisioneiro foi o inventor da 'má consciência'" (Id., p. 318-319).

Na experiência cotidiana comum, "má consciência" é a que censura retroativamente e faz sentir culpa/dívida; já a "boa consciência" é a que adverte prospectivamente. A propósito, convém ainda mencionar M. Scheler. Este pensador, atendo-se à dimensão vulgar do cálculo e compensação de "culpa" e "não-culpa" das ocupações, procurou elaborar uma interpretação da "boa" consciência que não fosse escrava do farisaismo (ST, II, p. 80). Definiu, então, a boa consciência como a experiência da certeza de não ter de se acusar, como a "falta vivenciada da má consciência" (Apud ST, II: 80).

Desses filósofos que antecederam a Heidegger, nenhum deles tentou interpretar ontologicamente o fenômeno da consciência (da culpa). Apoiado em Ser e tempo (a partir de agora: ST), este estudo enfrenta a seguinte questão: de que modo a constituição ontológica do ser humano torna possivel esse sentirse/compreender-se como sendo responsável por não ter praticado atos que deveria, ou por ter praticado atos que não deveria? Isto significa que o fenômeno da culpa é tratado a partir da pergunta (transcendental) pelas condições ontológicoexistenciais de possibilidade, é enfocado como um traço intrínseco ao modo de existir dos humanos.

O foco deste trabalho é, portanto, o conceito ontológico-existencial de serculpado/devedor [Schuldigsein], elaborado por Heidegger no § 58 de ST, enquanto um conceito pré-ético, pertinente às condições a priori de possibilidade da moralidade do ser-aí humano.

Considerando que este estudo concretiza a opção de trilhar o caminho aberto por ST - uma obra filosófica escrita em língua alemã - cumpre alertar no começo para uma particularidade atinente à palavra que os alemães empregam para designar o que em Português chamamos culpa. A palavra alemã Schuld, usada para designar culpa, também significa divida. É só prestando atenção ao modo como é usada a palavra Schuld que o ouvinte ou leitor sabe se ela significa culpa ou dívida ou, simultaneamente, os dois fenômenos. Em ST, Schuld sempre significa ao mes- 
mo tempo culpa e dívida; por isso, ao longo deste estudo, é usada a expressão culpa/divida, ligándo com barra os termos componentes.

As melhores abordagens filosóficas do tema da culpa na atualidade partem da análise lingüística da "confissão dos pecados". Neste sentido, Finitud y culpabilidad, de Paul Ricoeur, tornou-se uma obra exemplar e de referência não só valiosa mas também obrigatória. Esta abordagem (analítica), em vez de excluir, reclama o tratamento fenomenológico-hermenêutico. Não é fortuito que Ricoeur tenha procurado transformar os símbolos do mal em conceitos ontológico-existenciais, particularmente em $O$ conflito das interpretações. Assim, partindo da abordagem lingüística, Ricoeur encaminhou a reflexão sobre a culpa para a abordagem fenomenológico-hermenêutica, muito embora discorde expressamente de alguns conceitos básicos de Heidegger. O trânsito pelo interior do campo de pensamento aberto por ST não exclui a possibilidade e a validade de recorrer oportunamente a esclarecimentos da Filosofia Analítica, especialmente de Paul Ricoeur e de Ennst Tugendhat.

A intenção de fidelidade ao método fenomenológico-hermenêutico requer que a questão da Ética e a questão da culpa como um de seus conceitos sejam tematizadas por referência primeira ao sum ("eu sou") do ser-ai humano (Heidegger I) e não aos principios epocais da história do ser (Heidegger II). Efetivamente há em ST uma investigação, pautada pelo método fenomenológico-hermenêutico, acerca das condições de possibilidade da experiência da culpa, tendo como base o modo específico de ser que corresponde ao dizer "eu sou". O presente estudo, mesmo sendo de corte ontológico, exclui de sua alçada pensar o ser em sua dinâmica historial como a origem da adjudicação das ordens que devem se tornar regra para o homem (Heidegger II). Em ST, obra de referência básica para este estudo, esta origem é pensada a partir da análise das estruturas desse ser especial que é a existência humana, "lugar" de desvelamento do ser. Aliás, diga-se de imediato que o ser humano ouvinte/falante, pelo fato de constituir o "ai" do desvelamento do ser, recebeu em ST a denominação de "ser-ai".

A forma escolhida para tratar da questão da culpa requer que se justifique a possibilidade da passagem do ontológico-existencial para o ético. Presume-se que os conceitos correlatos e complementares de "a-quem-importa-seu-ser" e "terque-ser-seu-ser" permitem a passagem do ontológico-existencial para o ético sem incorrer na falácia naturalística. Ora, para clarear o nexo existente entre estes dois aspectos, respectivamente, 0 ativo-projetivo e o passivo-afetivo do relacionar-se do ser-aí com seu ser, o presente trabalho obriga-se a reproduzir sinteticamente a proposta original e irrefutável de Heidegger, de elucidação do relacionar-se consigo mesmo, em geral, e da autodeterminação, em especial. A determinação do ser do ser-aí como Cuidado parece desempenhar um papel decisivo na elaboração desta proposta. Pode-se antecipadamente sugerir que o conceito transcendental de Cuidado tenha levado Heidegger a substituir a clássica polaridade ética ("altruísmo $\mathrm{x}$ egoísmo") por outra mais fundamental, pré-moral.

ST parece também permitir pensar a passagem da Ontologia para a Ética pela tematização da ligação subterrânea que existe entre a fala-cum-escuta e o núcleo ativo-projetivo do ser-aí, cujo ser foi determinado como Cuidado. É legítimo supor 
que a "ética originária" que Heidegger, na Carta sobre o humanismo, diz existir em ST seja a ética da prontidão para o deixar que as coisas sejam ditas, a ética da disposição de ouvir, de ouvir inclusive as falas dissonantes com o nosso atual sistema de crenças e desejos.

O enfrentamento da questão da culpa/dívida nos termos anteriormente definidos requer, obviamente, que seja justificada a sua inserçăo em ST, explicitando o papel do conceito ontológico-existencial de culpa/divida no roteiro dessa obra monumental. Este estudo antecipou a hipótese de que Heidegger deu forma ao conceito ontológico-existencial de culpa/dívida visando a explicitar com suficiente radicalidade os diferentes aspectos do negativo incrustado no modo de ser do seraí. O desdobramento da negatividade que corrói o ser do ser-aí, por suposição, proibe a crença na possibilidade da identidade entre o ser e o dever-ser, por maior que seja o empenho do ser-aí em afirmar o seu ser/estar-no-mundo. O conceito de ser-culpado/devedor parece radicalizar a concepção do ser-aí como um ser constitucionalmente polar, estruturalmente fissurado. Com isso, admite-se que a cul$\mathrm{pa/divida} \mathrm{permite} \mathrm{ser} \mathrm{tematizada} \mathrm{a} \mathrm{partir} \mathrm{de} \mathrm{um} \mathrm{ponto} \mathrm{de} \mathrm{vista} \mathrm{formal} \mathrm{que} \mathrm{deixa}$ entre parênteses os conteúdos empírico-psicológico-religiosos.

A suposição de que o ser-aí está em seu ser determinado também pelo negativo, não podendo haver nem sintese nem dissolução dos pólos opostos, suscita a pergunta pela relação entre $o$ ético e o trágico. O trágico impõe-se ao ético devido à condição (lançada) da liberdade que, ao se afirmar ativo-projetivamente, incorre de modo inelutável em uma certa negação passivo-afetiva de seu ser. Dito de outra forma: o trágico consiste em que a liberdade, ao pôr o mal, incorre no cativeiro que faz com que ela, sendo de certa maneira negada, não possa não fazê-lo. A questão é: com isso não se dissolve o ético? Admite-se na largada deste estudo que em ST, embora não de maneira explícita, é conservada a tensão entre o trágico e o ético. Que ST esteja perpassado por uma polaridade pressuposta nas formulações éticas não parece discutível, o que significa que o pólo do trágico apesar da ênfase recebida em virtude da insistência no horizonte temporal/finito do ser do ser-aí e na negatividade inerente a este ser - não chega a destruir o pólo do ético. É plausivel supor que uma adequada articulação dos pólos do trágico e do ético represente uma crítica à autojustificação mediante o cumprimento de regras e/ou realização de valores, e uma proposta de vigilância quanto à desmedida do homem da civilização tecnológica.

Este estudo pressupõe a distinçâo entre precondição constitutiva de sentido de possível verdade ou falsidade e condições de possibilidade de verdade dos enunciados, e se orienta pelo esclarecimento apeliano de que Heidegger tenha priorizado a investigação da precondição constitutiva de sentido. É de se supor que, em consequiência dessa prioridade, Heidegger tenha negligenciado a questão da validação intersubjetiva das escolhas pelo projetar-se ativo-volitivo do ser-aí humano, de modo que Heidegger se omite de fornecer e de apontar para onde encontrar critérios de distinção entre condutas justificadas e condutas não justificadas, entre culpa justificada e culpa não justificada.

A elaboração deste texto sobre um tema pouco comum nas rodas de debate filosófico, mas imponente na T'eologia e na Psicologia, pautou-se por uma concep- 
ção de que cabe à Filosofia, entre outras tarefas, a de desfazer mal-entendidos e clarificar conceitos e a de articular tais conceitos na compreensão englobante mais coerente e plausivel. Assim, em relação ao conceito de ser-culpado/devedor, convinha perseguir o objetivo de mostrar sua possível operacionalidade em elaborações éticas alternativás às de corte subjetivista. Mas, para tal, a opção de apoiarse em ST impunha a tarefa de mostrar que as afirmações heideggerianas sobre o relacionar-se do ser-aí com sua existência futura concernem às condições de possibilidade para o comportamento tanto egoísta quanto altruista do ser-aí humano, e que o existir no modo da autodeterminação é uma das condições de possibilidade do comportamento altruísta próprio/autêntico.

\section{1 - Orientações metodológicas}

Este estudo procurou situar-se no interior de ST enquanto obra de pensamento e captar-lhe simpaticamente o conteúdo, procurando fielmente seguir Heidegger no seu método. Admitiu-se que, onde a crítica se fizesse necessária ou conveniente, ela não deveria ser estranha ao paradigma em que o filósofo se situa, pois, por mais tensa que possa se tornar qualquer interlocução, para que ela não seja aniquilada, requererá dos envolvidos um mínimo de linguagem, regras e pressupostos conceituais compartilhados.

A leitura de ST, priorizando a questão do relacionar-se do ser-aí consigo mesmo e focalizando particularmente o parágrafo 58 , procurou seguir as seguintes orientações metodológicas:

a) a análise do ser-aí pretende ser Ontologia Fundamental; portanto, o ser-aí é analisado como o ente em cujo ser se desvela o Ser; trata-se de manter rigorosamente a distinção entre ser-aí que compreende o (seu) ser e ser-humano no sentido antropológico; em ST, o ser-aí é determinado como o "ai" do desvelamento do ser: todo o nosso compreender é, de alguma maneira, acompanhado pela compreensão dessa palavra elementar, o verbo "ser", irredutivel a determinada representação subjetiva;

b) a análise do ser-ai, enquanto Ontologia Fundamental, perfaz uma rigorosa reflexão transcendental, isto é, uma busca criteriosa das condiçōes ontológicoexistenciais de possibilidade da experiência ôntica do ser-ai; por isso há que se manter sistematicamente a distinção entre o nivel ôntico-empirico e o nível ontológico-transcendental;

c) a reflexão ontológico-transcendental a respeito da existência do ser-aí humano concentra-se na descrição fenomenológica da forma, do modo de ser, do "como", deixando de lado a questão dos conteúdos vivenciais da existência; a mesma distinção é aplicada à questão da culpabilidade;

d) a interpretação do ser do ser-aí em sua relação originária com o mundo busca desvendar um âmbito anterior à distinção entre sujeito e objeto, pois a relação-de-ser que vigora entre o ser-ai e seu próprio ter-que-ser não é um representar nem é consciência de algo, ou seja, não pode ser concebida como autoobjetificação; assim, o "como" desvendado por Heidegger, isto é, a estrutura do relacionar-se consigo mesmo, em geral, e da autodeterminação, em especial, não é 
apofântica, mas hermenêutica, e a transcendentalidade é dessubjetivada e mundanizada (Stein);

e) a interpretação ontológico-existencial dos fenômenos do ser/estar-aí-nomundo parte sempre da interpretação vulgar ou cotidiana, desmontando-a e aproveitando dela o que convém, em base ao critério ontológico-existencial do "eu sou"; a crítica mais notável e freqüente à interpretação vulgar é que ela trata o ser-ai com categorias pertinentes aos entes puramente subsistentes e aos utensilios; em outras palavras, a interpretação cotidiana trata o "sou" do ser-aí como mera variante gramatical do "é" constatativo; ST zela ininterruptamente por manter.a distinção entre o sentido prático-auto-referencial do "sou" ("existência") e o sentido teórico-constatativo do "é" (ser puramente subsistente);

f) as proposições a respeito do ser-aí formuladas na terceira pessoa são traduziveis para proposições de primeira (ou segunda) pessoa do singular sem distorção de sentido porque o ser do ser-ai é em cada caso o meu (ou o teu) ser, quer dizer, o ser-aí se caracteriza pela singularidade irredutível (Jemeinigkeit);

g) como o ser-aí é dotado ao mesmo tempo de uma transcendentalidade e de uma temporalidade, pois o horizonte que regula o ser do ser-aí é a temporalidade da ordem transcendental (Stein, 1993, p. 35, 111, 283), os predicados formais do ser-aí devem ser cuidadosamente distinguidos das categorias atribuiveis às coisas puramente subsistentes e aos utensilios; para designar essa articulação das idéias de formalidade e temporalidade, Heidegger escolheu o termo existenciais;

h) ST concretiza o circulo hermenêutico: antecipa pressupostos e se movimenta para a confirmação dos mesmos, mediante a exibição dos fenômenos; é através do movimento circular da hermenêutica que está colocada a questão da validez da Analítica do ser-aí, em ST;

i) o método heideggeriano admite e exige a complementação da Filosofia Analítica para a otimização do esclarecimento de suas descobertas, quaseintuitivas, mas pregnantes por formulaçōes em termos intersubjetivamente controláveis.

\section{2 - A estrutura do relacionar-se consigo mesmo, em geral, e da autodeterminação, em especial: o ser do ser-aí e a possibilidade do dever}

O propósito de elaborar a questão do modo como o ser (em geral) se mostra a partir de si atraiu Heidegger para a questão transcendental da compreensão do ser: o ser, para poder se revelar, depende de ser compreendido; depende do ser-ai que se relaciona com seu ser/estar-no-mundo prático-significativo.

Priorizando a tematização das condições de constituição de sentido face à das de validação intersubjetiva do mesmo, o filósofo se guiou pelo princípio metodológico de que, à medida que'se desvela, o ser também se encobre (Stein). A forma sob a qual em ST está posta na linguagem a polaridade de velamento e desvelamento é a explicitação da polaridade entre decair de si e apropriar-se de si (Gadamer), visto que o projeto filosófico desta obra foi o de explicitar o até-entãoimpensado sentido de "eu sou". O filósofo pressupōe que o ser-aí compreende o 
ser em geral porque compreende seu próprio ser com o qual se relaciona, afirmando-a ou negando-a (Tugendhat).

Ao dizer "eu sou", o ser-aí não simplesmente constata seu ser, mas relacionase com ele como o ser que, ao mesmo tempo, lhe importa e tem-que-ser. 0 primeiro aspecto, o ativo-projetivo, concerne à condição de antecipar-se em possibilidades; o outro, o passivo-afetivo, diz respeito à condição de já-sempre estar lançado em determinadas possibilidades e já-sempre estar jogado na responsabilidade intransferivel de realizar a existência que tem a sua frente, queira ou não. Há, portanto, um dever por assim dizer radicado no ser do ser-ai humano: o dever de assumir seu próprio ser como seu, o dever de cuidar de sua existência futura.

Ao conceito de cuidar da própria existência futura estão indissoluvelmente vinculados outros dois conceitos ontológico-existenciais, o de temporalidade e de mundo. Heidegger chama "temporalidade ekstática" à estrutura unitária dos fenômenos do ser-adiante-de-si (vir-a-si), do já-ser-em (retornar-a-si) e do ser-junto-a (atual deixar-vir ao encontro). E chama "mundo" à totalidade estruturada de significados e intenções inter-relacionados, à totalidade das situações práticas enquanto campo em que o ser-aí pratica o jogo do existir. O tempo se dá fundamentalmente desde o que-fazer prático do ser-aí no mundo. A atribuição de prioridade à dimensão ekstático-existencial do futuro, pelo autor de ST, visa a exprimir que, em cada momento, nós nos relacionamos com o nosso existir futuro. Este existir já nos tem sido dado como o que temos que ser e como esse que para nós importa. Enquanto nos relacionamos com nosso ter-que-ser, dizemos "sim" ou "não" a ser/atuar desta ou daquela maneira (Tugendhat). Tendo descoberto a temporalidade ekstático-kairológica como o sentido do ser do ser-ai (Cuidado), o filósofo assume que é a partir dessa temporalidade que se determina a compreensão do ser e que, portanto, dela emergirá o sentido do ser em geral (Stein).

ST foi a primeira obra da História da Filosofia que apreendeu com justeza o vínculo interno entre a possibilidade prática e a necessidade prática de ser do seraí humano. Encontrar-se em uma determinada situação prática é o momento de inevitável facticidade. Mas toda è qualquer situação prática, por definição, inclui um campo de jogo de possibilidades, ou seja, um espaço de alternativas possiveis; inclusive a situação prática fundamental, que é a facticidade de ter-que-ser: é-me imposto realizar meu ser, mas a maneira como quero realizá-lo me é dado escolher pelo campo de jogo de possibilidades.

ST visivelmente se deteve na pergunta prática fundamental, na qual o ser-aí em cada caso questiona sua existência como um todo. Ao decidir acerca do modo como quer existir, o ser-aí inevitavelmente antecipa a totalidade de sua existência. Não há nenhum modo possivel de ser/atuar que não seja precedido e acompanhado pela possibilidade da impossibilidade de ser (Stein). A possibilidade da existência só se percebe em conjunto com sua negação, o que significa que só chego à confrontação, exigida nas decisões vitais, com minha existência como tal na simultânea confrontação com o possível fim de mim mesmo a cada momento (Tugendhat; Gaarder). A finitude constitui notoriamente o ângulo de contraste da Ontologia Fundamental com a tradição ontoteológica, com inevitáveis repercussões no campo da Ética (Stein, Loparic, Rorty). 
Por sua constituição ontológıca a priori, o ser-aí não é necessariamente um ser moral. Ele pode sê-lo como pode não sê-lo. A entrada numa comunidade moral depende do querer do ser-aí em cada caso. O método fenomenológicohermenêutico não permite que se deduza da idéia (transcendental) de ter que cuidar da própria existência futura a idéia de um determinado dever-ser ôntico. Ontológico-existencialmente, o ser-aí está lançado tanto na possibilidade de seguir, quanto na de transgredir regras. Levar a sério o princípio da autonomia implica jogar ao lixo da História da Filosofia a pretensão de fundamentação absoluta da Ética.

À obsessão ontoteológica pela idéia da fundamentação absoluta da Ética deve-se erguer o anteparo da metáfora de um fundamento cheio de buracos (Stein), um fundamento minado de não-ser. A observância de regras por parte do ser-aí sustenta-se em seu modo prático de ser/estar no mundo histórico, pois desde sempre ele está familiarizado com, está junto a, é-com. Mas apreendido/experienciado desde o seu reverso, como estranho/estrangeiro (unheimlich), o ser-no-mundo é sem-fundamento, é sem-sustentação na história herdada; as regras vigentes não contam. As experiências intermitentes de confrontação com esse reverso do ser-no-mundo familiar põem o ser-ai face à alternativa de assumirse no modo da autodeterminação ou de incessantemente recorrer a expedientes de encobrimento do "buraco" ekstático-temporal da existência.

Com relação ao aspecto ativo-projetivo do cuidar da existência, Heidegger desenvolveu em ST, entre outras, as seguintes idéias: a) incumbe ao ser-aí a responsabilidade da possibilidade de ser/agir, cuja peculiaridade existencial é aferivel mediante o critério lingüístico "posso se quero"; b) o conceito de possibilidade existencial pressupõe a clássica distinção entre querer imediato - as inclinações e o querer que delibera - a vontade no sentido estrito; c) a abertura específica do ser-aí como ser possivel é a compreensão, cuja estrutura existencial consiste no projetar-se em possibilidades futuras de ação; d) o compreender é, ao mesmo tempo, um saber teórico de que me encontro neste ou naquele estado e um saber prático quanto à minha possibilidade de atuar desta ou daquela maneira; e) à abertura que o ser-aí é em virtude da compreensão liga-se a liberdade como determinação ontológica de um ente que se conduz em relação a si mesmo e em cuja conduta o seu ser está sempre em jogo; f) a explicitação do caráter intransferivel da responsabilidade do ser-aí para com as possibilidades de ação escolhidas e realizadas desautoriza a objeção de fatalismo a Heidegger; g) a antecipação da possibilidade da impossibilidade liberta 0 ser-aí do perder-se nas possibilidades ocasionais, além de romper todo e qualquer enrijecimento da existência já alcançada.

A respeito da condição passivo-afetiva de não poder me furtar ao relacionarme com o meu ser, cabe, também, destacar algumas idéias de ST: a) o ter-que-ser incide sobre o ser-aí, sem consulta prévia, como o encargo intransferivel de terque cuidar de seu ser, queira ou não; b) pelo fato de o de-onde e o para-onde não poderem ser racionalmente explicados, o ser-aí sente-se "atirado aí"; c) Heidegger tematizou os afetos e estados de ânimo com relação a este encontrar-se atirado aí, que precede e ultrapassa os alcances de abertura de qualquer conhecimento e 
vontade; d) o fato de existir desvela-se, no plano afetivo, numa escala que vai desde os estados de ânimo deprimentes até os leves, escala correspondente à polaridade do experienciar a vida sem-sentido e do experienciá-la plena de sentido; e) a idéia da facticidade impede desvincular a liberdade da restrição das possibilidades, o que Heidegger viu com clareza suficiente para ficar imune da objeção de decisionismo: por força dessa sua marca registrada que é a condição de estar jogado, o horizonte do ser-aí é um horizonte sempre determinado historicamente (Stein); f) quando relacionado à questão da Ética, o tema da facticidade exige a articulação do ético com o trágico; g) a condição de estar jogado em determinadas possibilidades inclui o estar jogado na possibilidade da impossibilidade de existir; h) o vínculo do sentir-se atirado aí com o compreender-se enquanto projeto se desvela quando sofro no estado de ânimo a repercussão do êxito e do fracasso da minha busca arriscada de sentido da existência como um todo.

Pelo fato de no ser-ai estar em jogo o seu ser-no-mundo, ele pode negligenciar sua tarefa de apropriar-se de si e mover-se no modo existenciário da inautenticidade (Uneigentlichkeit). Não se trata de uma diminuição ou degradação ou carência ontológico-existencial (ST, I, p. 78, 237), mas de um movimento existenciário de extravio e dispersão, por conta do desincumbir-se do encargo da autodeterminação. Tal decaimento de si mesmo é motivado pela agrura do sentimento de estrangeireza (Unheimlichkeit) do ser-aí em seu ser-no-mundo e pelo desamparo no qual já não podemos ater-nos a nossos pré-julgamentos. O decair de si é a estrutura fundamental que permite pensar qualquer fato ético negativo em sua condição de possibilidade (Stein). Um aspecto interessante do decaimento é que quem vive nele desconhece o seu sentido. Este só é descoberto a posteriori, só pode ser descrito a título de situação passada. Ninguém pode traduzir em técnica prática o seu singular e tórtuoso caminho de passagem para o modo próprio/autêntico de ser. Embora avesso à idéia de uma pedagogia moral, Heidegger elaborou uma interpretação das estruturas ontológicas do ser-aí, servindo-se do modo autodeterminante de existir para modelo ôntico-existenciário.

Assim como o ser-aí pode, por negligência, decair de si, ele, unicamente ele, pode retirar-se da perdição no impessoal. É questão de querer, é questão de ser ou não ser eu-próprio. A alternativa é: ou eu eludo ou eu mesmo enfrento e respondo à pergunta prática fundamental acerca do que eu quero da minha vida em sua totalidade. O que está na base das tomadas de posição do ser-aí, em cada momento, relativamente ao seu existir futuro? A resposta heideggeriana é categórica: ser próprio/autêntico e ser impróprio/inautêntico constituem modos existenciários que se diferenciam e contrastam em base ao critério lingüistico "a quem dás ouvido?" Cada ser-aí pode dar ouvidos ao que todo mundo diz, como também pode dar ouvidos a si-mesmo próprio, isto é, aos reclamos do Cuidado por sua existência futura. No primeiro caso fica fechado em seu sistema de crenças e desejos, rigidamente apegado a seus pré-julgamentos. No segundo, abre-se às vozes, mesmo dissonantes com seu atual sistema de crenças e desejos, as quais otimizam a tarefa de cuidar de sua própria existência no processo histórico que corrói a autoridade das medidas pré-estabelecidas. No primeiro caso, não se leva a sério; 
no segundo, assume responsavelmente seu ter-que-ser, suportando o risco moral requerido pelo existir no modo da autodeterminação.

As reflexões de ST são, portanto, particularmente pertinentes para o querer de última instância, em que nossa vontade está dirigida à própria vida como um todo, está empenhada na busca de sentido; reconhecidamente, nestas decisões de segunda ordem já não podemos, sem mais, apoiar-nos em razões de validade intersubjetiva, ou seja, em normas morais, em histórias narradas, em hábitos compartilhados. Heidegger tem sido criticado por não ter explicitado as condições de validação intersubjetiva racional das nossas decisões (Tugendhat). Mas não se pode deixar de reconhecer a perspicácia com que o filósofo desmascarou o caráter ilusório, supostamente racional, de salvar-se cumprindo normas sociais e/ou realizando valores.

Os outros ser-aí, filosoficamente, não constituiam problema para Heidegger. 0 ser-com-os-outros no mundo compartilhado não precisava ser demonstrado. Eu sempre já existo com os outros, pois desde sempre existo no espaço mediado pela linguagem compartilhada. O ser-com-os-outros foi existencialmente interpretado como um fenômeno do Cuidado. O ser-com-os-outros, cujo ser também é Cuidado, assenta-se na possibilidade de ouvir. O problema que Heidegger viu com rara lucidez foi o da escolha auditiva entre discursos alternativos. Com relação a este assunto, não se pode esquecer: a) a partir de vários flancos, Heidegger golpeou mortalmente a concepção subjetivista-individualista do ser-aí humano; b) faz uma interpretação distorcida de ST quem afirma estar contido nesta obra uma ética monológica.

Em consonância com o postulado de que o ser-aí concreto já anda perdido e deve se reapropriar de si-mesmo, ST é perpassado pela polaridade abstrata entre o admissivel e 0 inadmissivel, pressuposta em todas as formulações éticas. $O$ presente estudo aceitou como condizente com o texto de ST a interpretação tugendhateana da polaridade dos modos existenciários de ser nos termos da polaridade de conduzir-se no modo da seriedade - a si e aos demais - e de seguir as inclinações imediatas do momento, deixando de tomar a sério a si e aos demais. Com efeito, trata-se de duas formas alternativas, uma afirmativa e outra negativa, de relacionar-se com a existência própria e dos outros. A priorização da interpretação ontológica do "eu sou" exigiu do filósofo a substituição da polaridade ética "amor-a-si x amor-a-outros" pela polaridade "levar-se a sério x não-levar-se a sério". Esta é, sem dúvida, uma das contribuições mais notáveis de ST para a Ética. Está comprovado que entre o levar-se a sério e o levar a sério os outros vige uma implicação mútua (Tugendhat). Assim, quem lê ST inadvertidamente a partir da chave que prioriza a polaridade "altruísmo x egoísmo" corre o risco de não compreender adequadamente o texto. Um aspecto relevante ligado a isso é que ST opera com o pressuposto, nem sempre levado a sério pelas formulações éticas tradicionais, de que ninguém pode ser despojado de seu relacionar-se consigo mesmo, cabendo a cada um realizar sua própria autonomia. Mesmo que alguém se entregue, seja a outro ser-aí seja a algum deus, ele dispõe de si de tal maneira que jamais pode ser possuído por outro (ST, I, p. 240). 


\section{3 - Consciência e culpabilidade em Ser e tempo}

Que papel desempenha o conceito de ser-culpado/devedor no roteiro de ST? Qual é o seu significado dentro do texto? Quais as suas implicações para o pensamento ético?

Os temas da consciência e da culpabilidade, no texto de ST, estão situados na passagem da análise do ser-no-mundo cotidiano para a retomada do resultado desta análise sob a perspectiva da temporalidade. No interior mesmo dessa parte intermediária, o capítulo sobre a consciência é precedido pelo capítulo que trata do ser-para-a-morte. A justificativa metodológica para os dois capitulos é que: a) para ter-previamente o todo do ser do ser-aí há que se ter em conta que o ser-aí é, formalmente, ser-para-(com)-a-morte; b) para se deixar ver-previamente como próprio/autêntico, o ser-aí deve testemunhar sobre si mesmo no fenômeno da consciência. A elucidação existencial do ser do ser-aí em sua possivel totalidade e propriedade/autenticidade é metodologicamente assumida como condição sem a qual o método não apreenderia o modo como os fenômenos se dão a partir de si.

A maneira pela qual o conceito de consciência é introduzido no texto (§ 54) resulta numa brusca "desmoralização" da consciência (Ricoeur). A consciência é arrancada, de supetão, ao círculo venenoso de "boa" e "má" consciência, e só mais adiante (§ 59) esse golpe recebe uma justificação plausivel. No plano existencial, prévio àquele em que a consciência (moral) se orienta por normas compartilhadas, a consciência testemunha a possibilidade de o ser-aí se tomar de volta do impessoal, de re-apropriar-se, de recuperar-se.

Seguindo a pegada da interpretação cotidiana, o filósofo analisa o fenômeno da consciência como um evento lingüístico, como uma "voz"; mas, em oposição àquela interpretação, exclui dessa voz as clássicas funções de censura e advertência. Em virtude da "voz" da consciência, o si-mesmo torna-se capaz de retratar-se acerca da autonegligência escorada no que todo mundo diz e de retroceder para a origem inóspita de que constantemente foge. A descrição de Heidegger dá ênfase à dissimetria vertical entre a instância que apela e o si-mesmo apelado, reafirmando, no entanto, a imanência integral de ambos ao ser/estar-ai-no-mundo. O sistema de crenças e desejos do si-mesmo impessoal é afetado por gritos que vêm de fora dele - mas não de fora do ser/estar-aí-no-mundo - e que, por isso, soam estranho, causam impacto. Esses gritos têm a marca da violência porque apontam na direção inequivoca do assumir-se a si-mesmo próprio, o que implica suportar o desamparo de ter-que abrir mäo de pré-julgamentos sedimentados na forma de hábitos.

Heidegger sustenta que a voz da consciência não pertence ao grupo de fenômenos que se prestam à abordagem que constrói generalidades (conceitos e invariantes) a partir do estudo dos casos particulares. A pergunta sobre a universalidade da consciência ingenuamente repousa num mal-entendido quanto ao modo específico de ser do ser-aí. O chamado da consciência só atinge quem quer se recuperar da decaida de si-mesmo no impessoal. Há uma escuta possivel que corresponde a esse chamado; melhor dito, a estrutura existencial do ser-aí possibilita a este que se dê a si a possibilidade existenciária de um ouvir que interrompa o dar-ouvidos ao que "se" diz. 
Há, aos olhos do filósofo, uma íntima ligação entre o aspecto passivo-afetivo do ser-chamado pela voz da consciência e a não-escolha radical que afeta o serno-mundo, considerado do ângulo de sua inteira facticidade. À semelhança da imposição a mim, sem pedido nem consulta prévia, da existência, abate-se sobre mim a voz da consciência. Nem esta nem aquela se deixam fundamentar em sistemas racionais de crenças e desejos.

No estar-lançado (já-ser-em), o ser-ai angustia-se com seu poder-ser. O chamado da consciência aclama o ser-aí para sair da decaída (estar-junto-a) e o conclama a assumir o seu poder-ser mais próprio. Como, no fundo, o ser-aí é Cuidado, a voz da consciência é o clamor do Cuidado. Da consideração do Cuidado como um conceito transcendental segue que o procedimento de "desmoralização" da consciência não significa outra coisa que a sua transcendentalização no sentido prático-existencial. A voz da consciência no sentido existencial-temporal, ou seja, o clamor do Cuidado, é a condição de possibilidade da consciência moral própria/autêntica.

A questão da culpabilidade é introduzida no texto de ST estritamente em função da pergunta "o que o clamor do Cuidado dá a compreender?" A resposta do autor é categórica: que o ser-aí é-culpado/devedor. O clamor do Cuidado interpela o ser-aí como o que é-culpado/devedor. Assim, no ato de "confessar-se", o penitente diz: "eu sou-culpado/devedor". Por isso, o sentido formal existencial de culpa/dívida é determinado em base ao critério lingüístico de essa culpa/dívida surgir como predicado do "eu sou".

A idéia da culpa/divida deve, portanto, ser pensada a partir do modo existencial de ser do ser-ai; deve, por isso, ultrapassar o âmbito das ocupações em seu prestar contas e ser desligada de qualquer referência ao dever e à lei contra os quais o ser-aí, numa falta, assume uma culpa/divida. Ora, no relacionar-se do seraí com sua existência futura, o não-ser acompanha o ser como o seu reverso indissociável; ao dizer "sim" à sua existência, o ser-aí admite o "não" incrustado nela. De modo que o conceito formal de ser-culpado/devedor deve juntar a idéia de "eu sou" e a de "não". Seguindo a pista da interpretação cotidiana da culpa/divida, o filósofo encontra o "não" embutido na idéia (objetivista) da privação ou falta (relativamente à realização de um ideal valorizado). Da idéia cotidiana do "serresponsável-por", relacionada à culpa/dívida, o filósofo extrai a idéia de "eu sou fundamento de". Logo, eu sou e, ao mesmo tempo, não sou fundamento da minha existência futura. Ser-culpado/devedor significa então ser-fundamento de um ser determinado por um "não".

O ser-fundamento, ou seja, o ativo-volitivo projetar-se em possibilidades de ser, está desde sempre minado de negatividade. Antes que o ser-aí se torne (moralmente) culpado/devedor por obra de erros e omissões, ele sempre já éculpado/devedor. Ser-fundamento minado de negatividade é condição existencial a priori de possibilidade da culpa/dívida moral.

A negatividade permeia o ser-fundamento do ser-aí humano em dois níveis: ontológico e ôntico. A negatividade ontológica é inerente à condição de estar lançado, à facticidade em sentido estrito. Precede toda e qualquer iniciativa da liberdade. Corresponde-lhe a abertura passional-afetiva, pois năo admite explica- 
ção racional. Inerente ao ter-que-ser, impõe-se a todo e qualquer projetar como finitude estrutural. Relativamente ao obscuro de-onde, significa impossibilidade de se criar, não ter-se levado por si mesmo ao seu "ai", não ser seu próprio fundamento, não poder retornar aquém de seu estar-jogado. Relativamente ao ignorado para-onde, significa a possibilidade improjetável, sempre iminente, do não-(mais)estar-aí. O ser-fundamento de projetos está, portanto, prévia e estruturalmente, fissurado. Tal fissura pesa sobre o ser-aí como uma dívida impagável que the foi imposta sem consulta prévia e sem justificativa racional.

Em nivel ôntico, a negatividade se concretiza como reverso indissociável, voluntário ou involuntário, da afirmação ativo-projetiva da existência. A imagem do efeito colateral dos medicamentos talvez ajude a elucidar esta dimensão da negatividade. Alguns aspectos do desdobramento da negatividade em nível ôntico são citados a seguir: a) as possibilidades de agir para as quais o ser-ai se projeta não são ilimitadas, mas restringidas pela condição de estar-jogado; b) a projeção impli$\mathrm{ca}$, continuamente, o retraimento às possibilidades alternativas: poder-ser do seraí só é escolhendo uma possibilidade e não podendo escolher outra(s); c) existindo adiante de si, o ser-aí é, a cada momento, por aquilo que ainda-pode-ser e aindanão-é (Nunes); d) todos os projetos humanos são falhos, de uma ou de outra maneira, podendo ser sempre questionados e revogados por mim e/ou pelos outros, mas a fuga da culpa que advém desse "falhar", conforme o testemunho dos heróis trágicos, só aumenta a culpa (Loparic); e) todos os projetos restringem as possibilidades dos outros ser-aí, pondo em perigo a sua existência, levando-os por caminhos errados, ou até mesmo destruindo a sua existência (Loparic); f) quanto à realização de suas possibilidades de ser, o ser-aí pode supervalorizar desmedidamente suas possibilidades, sobrepassando-se por temeridade prometéica e extraviando-se de si-mesmo próprio (Condrau); g) ainda quanto à realização das possibilidades, pode o ser-ai, por negligência, não se apropriar das que lhe pertencem, de modo a ficar aquém da realização possivel de sua existência; h) finalmente, deve ser mencionado o "não" que determina o modo existenciário de ser da impropriedade/inautenticidade, que é o não-dar-ouvidos ao clamor do Cuidado. Em relação a este último aspecto não dá para esquecer que o cotidiano impessoal, por mais que possa ser dominado, nunca pode ser apagado (ST, II, p. 174).

Por esses aspectos da negatividade que perpassam o projetar-se do ser-aí, parece razoável admitir que a culpa/dívida é possivel não apenas devido à radical impossibilidade de se autofundar e à possibilidade da impossibilidade de continuar existindo. Não há apenas o peso dos aspectos passivo-afetivos do existir (facticidade). A idéia do ser-responsável é intrínseca à idéia do ser-culpado/devedor. Se os aspectos ativo-projetivos do existir não constituissem um peso/encargo, o ser-aí não estaria levando a sério as possibilidades de existir no futuro e, conseqüentemente, seria também indiferente em relação à facticidade. Só há experiência do inelutável porque há iniciativa da liberdade (Guardini). Sentimos culpa também em relação ao inelutável que cada um vai traçando ao dar forma à sua existência porque sempre podemos imaginar ter seguido outro caminho (Ricoeur). Até mesmo o acidente só pode ser experienciado como desordem e culpa sob a condição 
de que eu me sinta responsável pela estruturação do meu mundo-projeto, por ele golpeado.

Pelo visto, com o conceito de ser-culpado/devedor, Heidegger desfez algumas ilusões marcantes da cultura moderna: a) a ilusão do indivíduo de, pelo seu livre arbitrio, criar-se a si mesmo, produzir-se de acordo com projetos inventados por ele próprio; b) a ilusão da desalienação completa ou reconciliação plena a ser produzida pela tecnologia; c) a ilusão de salvar-se mediante o cumprimento de normas técnicas, morais e jurídicas, e/ou a realização de valores; d) ilusão de se furtar à precariedade do acontecer histórico mediante o apego a uma concepção totalizadora-infinitista da história, tipo Positivismo ou Hegelianismo.

O clamor do Cuidado pelo existir futuro dá a compreender, portanto, que o ser-ai, na possibilidade de ser, não é fundamento de seu ser, estando, irremediavelmente, em dívida e, por conseqüência, no dever de recuperar-se para si da perdição no impessoal. Quem ouve adequadamente o clamor do Cuidado sente-se estranhamente convocado a assumir o seu poder-ser-culpado/devedor mais próprio, pois o ser-livre para o ser-culpado/devedor é condição de possibilidade do assumir-se como ser-si-mesmo mais próprio.

O modo de existir, para o qual o Cuidado chama, sintetiza dois principios aparentemente opostos: a condução autônoma de si-mesmo e a aceitação sem mascaramentos do inelutável, da finitude, do negativo incrustado no próprio ser; este último princípio inclui o reconhecimento da condição de sempre já estar em dívida com os outros.

A prontidão para ouvir o clamor do Cuidado, a nível existenciário, otimiza cada um dos três elementos constituintes da abertura/revelação: a) a nivel do passivo-afetivo encontrar-se jogado-ai, suporta a fissura entre o sentir-se familiarizado e o sentir-se estranho/estrangeiro, entre o gozo do poder-sim-ser/estar-aí e a angústia de poder-a-qualquer-momento-não-mais-ser/estar-ai; b) a nivel do compreender-se ativo-projetivo, integra na autocriação a aceitação, em sentido próprio, da dívida/culpa em relação à herança, especialmente lingüístico-cultural; c) a nível do discurso, preserva a tensão estrutural entre a dimensão superficial do dizer e a dimensão profunda do escutar atento e silencioso do que a mim se dirige para poder discernir o clamor do Cuidado em meio à algazarra do que "se" diz.

Um bom observador nota que o autor de ST deu um "passo para trás" deste plano (ôntico-empírico) em que nosso comportamento moral está infectado pela interdição, e o imoral, pela arrogância. O que assim atingiu foi o "lugar" da escuta, um "lugar" pré-ético em que o agir não é ainda o fazer e, por isso, escapa à alternativa da teoria e da prática, da paixão e da ação, da obediência e da autonomia, da sujeição e da revolta. No acontecimento da fala, em que há o deixar que as coisas sejam ditas (escuta), já não sou o dono, já não simplesmente manipulo objetos. É exatamente nesta situação de não-domínio - de pertencer a - que reside a origem simultânea da obediência e da liberdade. $O$ deixar que as coisas sejam ditas, além de neutralizar toda acusação, dispensa o amparo buscado na fuga decadente para os entes intramundanos.

Heidegger detectou a conexão subterrânea existente entre a fala-cum-escuta e o núcleo ativo-projetivo da nossa existência. À fala pertence o poder de mudar a 
compreensão que temos de nós mesmos. Esse poder não é propriamente um imperativo, já que a fala só pode nos mudar. pela mediação da nossa prontidão para ouvir. Sob esta condição, que depende de nossa decisão, a fala nos atinge ao nivel do sistema de crenças e desejos, mediante o qual operamos ao nos projetar em possibilidades futuras de ação.

A prontidão para ouvir o clamor do Cuidado equivale à disposição para reestruturar o meu sistema de crenças e desejos, com vistas à otimização da afirmação ativo-projetiva da própria existência. Nesta afirmação se unem desejo e esforço (Ricoeur). A mesma afirmação ativo-projetiva pressupöe a abertura auditiva ao ser do ser-aí - ao seu e ao dos outros - como projeto lançado e não como objeto simplesmente dado. Tugendhat acha que 0 conceito de afirmação ativo-projetiva da própria existência exige ser complementado pelo conceito de afirmação valorativo-intersubjetiva, ausente em ST.

A tarefa de cuidar da existência própria e dos outros confronta-se inevitável e ininterruptamente com a negatividade que também a determina. Esta tarefa contém a marca primária e definitiva do esforço de recuperação, de re-apropriação, pois a tendência de decaída e encobrimento não é suscetível de ser apagada. 0 esforço ético há-de confrontar-se sempre com essa tendência, com vistas a dominá-la, amestramento este que implica romper com o que todo mundo diz. Mas o esforço ético esbarra também nos aspectos da negatividade ligados à facticidade. Nela encontra o inelutável. O Cuidado interpela o ser-aí em termos de aceitação do inelutável, de conformação com o irremovível. Não se trata aqui de resignação, mas, simplesmente, de aceitação modesta do ter-que-ser aquilo que originariamente se é. É em função deste ter-que-ser que o autor de ST apresenta a confrontação com a morte como uma condição (formal) necessária para que o ser-aí se recupere da perdição na arbitrariedade e casualidade das possibilidades de ação em que se encontra facticamente.

Quanto às pautas para determinar como, no escolher próprio/autêntico, abordam-se as possibilidades de ação, ST não definiu expressamente nada mais que o critério da confrontação com a morte, particularmente válido para as decisões que põem em jogo a vida como um todo. Deve-se ter em mente que ST não pretende ser um tratado de Ética. Não adiante cobrar-lhe, no caso, a formulação de um conceito de bem; o texto simplesmente não visa a isso. Mesmo assim, pode-se perguntar se a abertura auditiva, exigida pelo próprio método fenomenológicohermenêutico, aos outros ser-aí como história-projeto e não como objeto dado à visāo, e particularmente a ajuda aos outros para ficarem transparentes a si mesmos em seu Cuidado (antecipação liberadora), ficam devendo muito para o conteúdo do imperativo kantiano em suas diferentes formulações.

Antes de Heidegger, ninguém como ele havia conseguido com tanta justeza elaborar o conceito de autodeterminação. Contudo deve-se concordar com Tugendhat que a concepção heideggeriana de autodeterminação contém uma lacuna que exige ser preenchida, e essa lacuna diz respeito à relação da autodeterminação com a razão auto-reflexiva. A autodeterminação não se sustenta sem essa relação com a razão. 
O esforço moral de re-apropriação de si-mesmo tende a aguçar a sensibilidade relativa ao inelutável. Quanto mais estiver empenhado em determinar a partir de si o modo como quer existir, mais o ser-aí tem que suportar a dor consciente de nãoser sua própria criação. Afirmar a liberdade e promover o sujeito moral responsável implica tomar sobre si a origem do mal, isto é, do inaceitável que eu fiz e teria podido não fazer. $\mathrm{O}$ trágico na relação entre a liberdade e o mal é que este apenas é mal enquanto eu o ponho, mas no próprio coração desse pôr do mal pela liberdade revela-se o cativeiro que faz com que eu não possa não fazer o mal de que também me declaro responsável. Esse aspecto não cometido, encerrado em todo cometer o mal, tende a ser representado como uma "sina", como uma dobra contraída da liberdade. O paradoxo de uma constituição passiva que afeta a vontade $e$ está implicada em seu poder de deliberação e escolha é designado pela expressão polar "servo arbitrio". Heidegger não tratou expressamente dele; mas o caráter passivo do ser-culpado/devedor, indissociável da responsabilidade de assumir-se ativamente como ser-possivel, e a aceitação do ser-culpado/devedor como condição de propriedade/autenticidade, parecem sugerir o paradoxo de uma liberdade a ser libertada precisamente da escravidão a que ela mesma, ao se pôr em ação, entrega-se. Neste sentido, em ST o trágico se articula coerentemente com o ético: complementa-o, sem se deixar reduzir a ele.

Ao explicitar o nexo entre a análise ontológico-existencial e as experiências cotidianas da culpa/divida, o filósofo fornece uma ilustração adicional da fecundidade e da sutileza de seu método; ele mostra, entre outras coisas, que: a) a consciência cotidiana, em vez de sentir-se conclamada para assumir o ser-culpado/ devedor, nele se debate visando à fuga; b) a busca do sentir-se livre da culpa/ dívida é operada pela auto-interpretação cotidiana da consciência numa compreensão mercantil e administrativa da existência e do mundo, compreensão que se mantém na dimensão do cálculo e da compensação e se preocupa em contabilizar deveres e haveres. Nessa dimensão, que é a da temporalidade imprópria, não há outra alternativa para a má consciência que o farisaismo.

\section{Referências bibliográficas}

APEL, Karl-Otto. "É a morte uma condiçāo de possibilidade de sentido?" In: DE BONI, Luís A. (org.). Finitude e transcendência. Festschrift em homenagem a Ernildo J. Stein. Petrópolis: Vozes, 1996. BOSS, Medard. Angústia, culpa e libertação. São Paulo: Duas Cidades, 1975.

COHN, Priscila N. Heidegger, su filosofia a través de la nada. Madrid: Guadarrama, 1975.

CONDRAU, Gion. Angustia y culpa. Problemas fundamentales de la psicoterapia. Madrid: Gredos, 1968.

DEVIGII, Gamaliel. "Hermenêutica do Ethos". In: Revista Eclesiástica Brasileira, v. 34, fasc. 133, mar. 1974. p. 5-19.

ETXEBERRIA, Xavier. Etica básica. Bilbao: Universidad de Deusto, 1995.

GADAMER, Hans-Georg. Verdad y método. Salamanca: Sigueme, 1984.

GARCIA, Ramon Rodriguez. Heidegger y la crisis de la epoca moderna. Madrid: Cincel, 1987.

GUARDINI, Romano. Liberdade, graça e destino. Aster: Lisboa, s.d.

HEGEL, Georg W. F. A razăo na história. São Paulo: Moraes, 1990.

HEIDEGGER, Martin. Ser e tempo. Parte I (ST, I). 4. ed. Petrópolis: Vozes, 1993.

- Ser e tempo. Parte II (ST,II). 3. ed. Petrópolis: Vozes, 1993.

__. "Sein und Zeit". In: Gesamtausgabe. I. Abteilung: Veröffentlicht Schriften 1914-1970. Band

2. Frankfurt am Main, Vittorio Klostermann, 1977. 
- Conferências e escritos filosoficos. 2. ed. São Paulo: Abril Cultural, 1984.

KANT, Emmanuel. Textos selecionados. 2. ed. São Paulo: Abril Cultural, 1984.

- Crítica da razão prática. São Paulo: Ediçōes e Publicações Brasil Editora, s.d.

KUTSCHERA, Franz von. Fundamentos de ética. Madrid: Cátedra, 1989.

LEVINAS, Emmanuel. Ética e infinito. Lisboa: Ediçōes 70, s.d.

LOPARIC, Zeljko. Heidegger réu. Campinas: Papirus, 1990.

- Ética e finitude. São Paulo: EDUC, 1995.

LUIJPEN, W. Introdução à fenomenologia existencial. São Paulo: EPU, 1973.

MARTEN, Rainer. "Martin Heidegger: o tempo autêntico". In: DE BONI, Luis A. (org.) Finitude e transcendência. Festschrift em homenagem a Ernildo J. Stein. Petrópolis: Vozes, 1996.

NIETZSCHE, Friedrich. "Para a genealogia da moral". In: Obras incompletas. São Paulo: Abril Cultural e Industrial, 1974.

NUNES, Benedito. Passagem para o poético. 2. ed. Säo Paulo: Ática, 1992.

- "Filosofia e tragédia: labirintos". In: NUNES, Benedito et al. Filosofia politica 7. Porto Alegre: L\&PM, 1993.

OLIVEIRA, Manfredo A. Reviravolta lingüístico-pragmática na filosofia contemporânea. São Paulo: Loyola, 1997.

PEN̂ALVER, Patricio. Del espirito al tiempo. Lecturas de "El Ser y el tiempo" de Heidegger. Barcelona: Anthropos, 1989.

PLATẢO. Êutifron. Apologia de Sócrates. Criton. Lisboa: Verbo, 1972.

PÖGGELER, Otto. El camino del pensar de Martin Heidegger. Madrid: Alianza, 1993.

RICOEUR, Paul. Finitud y culpabilidad. Madrid: Taurus, 1982.

- O si mesmo como um outro. Campinas: Papirus, 1991.

- .0 conflito das interpretaçōes. Porto: Rés, s.d.

- Interpretação e ideologias. 3. ed. Rio de Janeiro: Francisco Alves, 1988.

RORTY, Richard. Ensayos sobre Heidegger y otros pensadores contemporáneos. Barcelona: Paidós, 1993.

. Contingência, ironia e solidariedade. Lisboa: Presença, 1992.

STEIN, Ernildo. Compreensão e finitude. Porto Alegre: Ética, 1967.

Melancolia. Porto Alegre: Movimento, 1976.

— Seis estudos sobre "Ser e tempo". 2. ed. Petrópolis: Vozes, 1990.

__... A questão do método na filosofia. 3. ed. Porto Alegre, Movimento, 1991.

- Seminário sobre a verdade. Petrópolis: Vozes, 1993.

- Aproximaçōes sobre Hermenêutica. Porto Alegre: EDIPUCRS, 1996.

— . A caminho de uma fundamentação pós-metafisica. Porto Alegre: EDIPUCRS, 1997.

TUGENDHAT, Emst. Problemas de la Ética. Barcelona: Crítica, 1988.

- Autoconciencia y autodeterminación. Madrid: Fondo de Cultura Económica, 1993.

—. Liçōes sobre ética. Petrópolis: Vozes, 1997. 